\title{
Non-thermal Plasma Induces Apoptosis in Melanoma Cells via Production of Intracellular Reactive Oxygen Species
}

\author{
Rachel Sensenig ${ }^{1}$, Sameer Kalghatgi ${ }^{2,6}$, Ekaterina Cerchar ${ }^{1}$, Gregory Fridman ${ }^{3}$, Alexey \\ Shereshevsky ${ }^{1}$, Behzad Torabi ${ }^{4}$, Krishna Priya Arjunan ${ }^{3}$, Erica Podolsky ${ }^{1}$, Alexander \\ Fridman $^{5}$, Gary Friedman ${ }^{2}$, Jane Azizkhan-Clifford ${ }^{4}$, and Ari D. Brooks ${ }^{1}$ \\ ${ }^{1}$ Department of Surgery, College of Medicine, Drexel University, Philadelphia, PA 19102, USA \\ Electrical and Computer Engineering, Drexel University, Philadelphia, PA 19104, USA \\ ${ }^{3}$ School of Biomedical Engineering, Drexel University, Philadelphia, PA 19104, USA \\ ${ }^{4}$ Molecular Biology and Biochem, College of Medicine, Drexel University, Philadelphia, PA 19102, \\ USA \\ ${ }^{5}$ Department of Mechanical Engineering and Mechanics, Drexel University, Philadelphia, PA \\ 19104, USA \\ ${ }^{6}$ Department of Biomedical Engineering, Centre for Advanced Biotechnology, Boston University, \\ ERB 301, 44 Cummington St, Boston, MA 02215, USA
}

\begin{abstract}
Non-thermal atmospheric pressure dielectric barrier discharge (DBD) plasma may provide a novel approach to treat malignancies via induction of apoptosis. The purpose of this study was to evaluate the potential of DBD plasma to induce apoptosis in melanoma cells. Melanoma cells were exposed to plasma at doses that did not induce necrosis, and cell viability and apoptotic activity were evaluated by Trypan blue exclusion test, Annexin-V/PI staining, caspase-3 cleavage, and TUNEL ${ }^{\circledR}$ analysis. Trypan blue staining revealed that non-thermal plasma treatment significantly decreased the viability of cells in a dose-dependent manner 3 and $24 \mathrm{~h}$ after plasma treatment. Annexin-V/PI staining revealed a significant increase in apoptosis in plasma-treated cells at 24,48 , and $72 \mathrm{~h}$ post-treatment $(p<0.001)$. Caspase- 3 cleavage was observed $48 \mathrm{~h}$ postplasma treatment at a dose of $15 \mathrm{~J} / \mathrm{cm}^{2}$. TUNEL ${ }^{\circledR}$ analysis of plasma-treated cells demonstrated an increase in apoptosis at 48 and $72 \mathrm{~h}$ post-treatment $(p<0.001)$ at a dose of $15 \mathrm{~J} / \mathrm{cm}^{2}$. Pre-treatment with $N$-acetyl-L-cysteine (NAC), an intracellular reactive oxygen species (ROS) scavenger, significantly decreased apoptosis in plasma-treated cells at 5 and $15 \mathrm{~J} / \mathrm{cm}^{2}$. Plasma treatment induces apoptosis in melanoma cells through a pathway that appears to be dependent on production of intracellular ROS. DBD plasma production of intracellular ROS leads to dosedependent DNA damage in melanoma cells, detected by $\gamma$-H2AX, which was completely abrogated by pre-treating cells with ROS scavenger, NAC. Plasma-induced DNA damage in turn may lead to the observed plasma-induced apoptosis. Since plasma is non-thermal, it may be used to selectively treat malignancies.
\end{abstract}

(C) 2010 Biomedical Engineering Society

Address correspondence to Sameer Kalghatgi, Department of Biomedical Engineering, Centre for Advanced Biotechnology, Boston University, ERB 301, 44 Cummington St, Boston, MA 02215, USA. suk22@drexel.edu.

The first two authors have contributed equally to this work. 


\section{Keywords}

Apoptosis; Non-thermal plasma; Reactive oxygen species; Cancer therapy; Plasma medicine

\section{INTRODUCTION}

Apoptosis, or programmed cell death, ${ }^{7,44}$ is a critical element of cellular self-regulation, which is a vital function in multi-cellular organisms allowing for appropriate growth, development, and death at the necessary times. The non-functioning of a tumor-suppressor gene or the over expression of an anti-apoptotic protein are both important pathways in cancer development. Many anti-cancer therapies are aimed at modulating these factors with various drugs in an attempt to target components of the apoptotic pathway. ${ }^{21,52}$ However, many of these approaches remain in preclinical development secondary to low efficacy and drug resistance. ${ }^{20,54}$ Our current research seeks to develop techniques to modulate apoptotic activity in cancer cells by evaluating an electro-physical approach to induce apoptosis.

We sought to explore the effects of exposure of melanoma cells to DBD plasma. We also attempt to present a few mechanisms underlying the induction of apoptosis by non-thermal plasma. The development and use of non-thermal plasma has been described by Fridman et al. ${ }^{14}$ Plasma, the fourth state of matter, is a partially ionized gas and was named by Irving Langmuir from blood plasma in the biological field. Despite this fact, electrical plasma is typically associated with high-energy physics employed in the semiconductor industry while rarely being used for medical applications. The few known uses of electrical plasma in medicine are based on the high temperatures generated by thermal discharges. Thermal plasma approaches, such as electrocautery ${ }^{43,48,51,60}$ and Argon Plasma Coagulator, ${ }^{2,17,50,68}$ are widely used in medicine today to rapidly coagulate blood and ablate tissue. $2,17,43,48-51,60,68$ However, they lead to significant thermal tissue damage. For these reasons, non-thermal room temperature electrical discharges where thermal damage is eliminated are being widely developed by various groups. ${ }^{14,23,64}$

Non-thermal DBD plasma has recently emerged as a novel tool in medicine. The operating principle of this plasma discharge is similar to the Dielectric Barrier Discharge (DBD) introduced by Siemens in $1862 .{ }^{59} \mathrm{DBD}$ plasma is generated at atmospheric pressure in air or other gases when high voltage of sinusoidal waveform or short duration pulses is applied between two electrodes, with at least one electrode being insulated. ${ }^{5}$ The insulator prevents build-up of current between the electrodes, creating electrically safe plasma without substantial gas heating. This approach allows direct treatment of biological systems without thermal damage that is observed in more conventional thermal plasmas. ${ }^{14,68}$ Our floating electrode dielectric barrier discharge (FE-DBD) plasma system is constructed similar to conventional DBD described above and is inherently non-thermal as it operates at room temperature. ${ }^{5,14,59}$ FE-DBD plasma operates under conditions where one of the electrodes is an insulated high voltage electrode, and the second (floating) active electrode is human (Fig. $1 b$ ) or animal tissue or organ; plasma is not generated in the absence of human or animal skin or tissue surface. ${ }^{14}$ Plasma is an ionized gas composed of charged particles (electrons, ions), electronically excited atoms and molecules, radicals, and UV photons. Plasma treatment exposes cells or tissue surface to active short- and long-lived neutral atoms and molecules, including ozone $\left(\mathrm{O}_{3}\right), \mathrm{NO}, \mathrm{OH}$ radicals, and singlet oxygen $\left(\mathrm{O}_{2}{ }^{1} \Delta_{\mathrm{g}}\right)$, and a significant flux of charged particles, including both electrons and positive and negative ions like super oxide radicals. ${ }^{9,12}$ Non-thermal plasma density, temperature, and composition can be changed to control plasma products. 
Non-thermal plasma has been widely used to sterilize animate and inanimate surfaces. ${ }^{14,18,36-40,61,64,66}$ It can be applied at sub-lethal doses to elicit specific biological effects, including gene transfection, ${ }^{3,4,42}$ cell detachment, ${ }^{32,33,64,65}$ growth factor release induced cell proliferation ${ }^{30}$, and wound healing. ${ }^{14,19,22,23,58}$ Non-thermal plasma can even have selective effects. In recent studies on plasma-initiated blood coagulation, ${ }^{14,23}$ skin sterilization, ${ }^{14,15}$ and tissue toxicity after plasma treatment, ${ }^{25,29}$ plasma did not demonstrate measurable toxicity in the surrounding living tissue. To date, there has been no investigation of the interaction between non-thermal atmospheric plasma discharges and the induction of apoptosis in cancer cells. This information is critical for non-thermal DBD plasma to be considered as a viable clinical cancer treatment tool.

\section{MATERIALS AND METHODS}

\section{Cell Lines and Reagents}

Melanoma cell line (ATCC A2058) was cultured in Dulbecco's modified Eagle's medium with $4 \mathrm{mM} \mathrm{L}$-glutamine adjusted to contain $1.5 \mathrm{~g} / \mathrm{L}$ sodium bicarbonate, $4.5 \mathrm{~g} / \mathrm{L}$ glucose (ATCC 30-2002), 10\% fetal bovine serum (ATCC 30-2020), and 1\% Penicillin/ Streptomycin (Sigma-Aldrich, St Louis, MO). The cells were propagated in 100-mm plastic petri dishes (Greiner Bio One) in a $5 \% \mathrm{CO}_{2}$ incubator at $37{ }^{\circ} \mathrm{C}$. Media was changed every 2-3 days. After 4-5 days of incubation when the cells reached $85-90 \%$ confluency, the cells were trypsinized $(0.25 \%(\mathrm{w} / \mathrm{v})$ Trypsin- $0.53 \mathrm{mM}$ EDTA) harvested, and transferred to $44-$ $\mathrm{mm}$ diameter aluminum Petri dishes (Fisher Scientific, Pittsburgh, PA). To improve the cell adhesion on aluminum petri dishes, the dishes were pre-treated with $0.01 \% \mathrm{w} / \mathrm{v}$ poly Llysine (PLL, 70-150 kDa) for $10 \mathrm{~min}$, prior to adding cells. Excess poly L-lysine was removed, and the plates were allowed to dry for $30 \mathrm{~min}$ at room temperature before plating cells. Experiments were begun 2 days after plating cells in aluminum dishes. The number of cells in each Petri dish at the beginning of each experiment was about $1 \times 10^{6}$ with 3-9\% being trypan blue positive.

Actinomycin D (Biovision Inc., Mountain View, CA), a potent inducer of apoptosis, was used as a positive control. $N$-acetyl-L-cysteine (NAC; 2 mM, Sigma-Aldrich, St Louis, MO), an intracellular reactive oxygen species (ROS) scavenger, was used to block intracellular ROS generation.

\section{Plasma Treatment of Melanoma Cells In Vitro}

Non-thermal atmospheric pressure DBD plasma was produced using an experimental setup similar to one previously described and schematically illustrated in Fig. 1. ${ }^{14,23}$ The nonthermal plasma was generated by applying alternating polarity continuous waveform (1.5 $\mathrm{kHz}$ ) voltage of $\sim 20 \mathrm{kV}$ magnitude (peak to peak) between the insulated high voltage electrode and the sample undergoing treatment using a variable voltage power supply (Quinta, Russia). A 1-mm thick, polished clear fused quartz was used as an insulating dielectric barrier covering the 1-inch diameter copper electrode. The discharge gap between the bottom of the quartz glass and the treated sample surface was fixed at $3 \mathrm{~mm} \pm 1 \mathrm{~mm}$. Discharge power density was measured to be roughly $1.0 \mathrm{~W} / \mathrm{cm}^{2}$ using both electrical characterization and a specially designed calorimetric system. Plasma treatment dose in J/ $\mathrm{cm}^{2}$ was calculated by multiplying the plasma discharge power density by the plasma treatment duration. For example, plasma treatment at a power density of $1 \mathrm{~W} / \mathrm{cm}^{2}$ for $15 \mathrm{~s}$ would correspond to a dose of $15 \mathrm{~J} / \mathrm{cm}^{2}$. Non-thermal DBD plasma produces various ROS in gas phase whose typical concentrations are provided in Table $1 .{ }^{10,12,13}$ The dependence of ROS concentration on plasma power density is extremely complex ${ }^{5,34}$. DBD plasma has a $\mathrm{g}$ factor (number of ROS generated per electron volt or eV) between 0.3 and $0.5 .{ }^{11}$ For a plasma dose of $3.9 \mathrm{~J} / \mathrm{cm}^{2}$, about $2 \times 10^{17}$ ROS are generated. 
Early experiments revealed that plastic Petri dishes prevented application of uniform plasma discharge to the cells. As an alternative, aluminum Petri dishes (Fisher Scientific) were used to plate and treat cells in vitro. The only drawback was the inability to observe the cells directly on the aluminum plates. For this reason, additional controls were prepared in parallel with standard Petri dishes of the same size. There was no significant difference in the growth rates of melanoma cells in PLL-coated aluminum dishes as compared to that in plastic petri dishes (Fig. 2). Melanoma cell growth patterns are important to note, because the inactivation results reported here are not due to lack of nutrition, cell age, or the influence of toxicity due to PLL or the aluminum substrate on the cell's life cycle. At the start of each experiment, all the media from each experimental or control Petri dish was aspirated, and $200 \mu \mathrm{L}$ of fresh growth medium was added to keep the cells moist. Cells were then exposed to non-thermal plasma, and $1 \mathrm{~min}$ after treatment, $2 \mathrm{~mL}$ of fresh media was added for further incubation until the time of analysis. Cells in dishes that were not exposed to plasma were used as controls and were processed similar to plasma-treated cells.

\section{Trypan Blue Exclusion Test}

Trypan blue exclusion was used in the initial dose response and time-course experiments using the following protocol. $1 \times 10^{6}$ Melanoma cells were seeded in aluminum petri dishes 2 days before plasma treatment. Cells were exposed to different doses of plasma and incubated for 1,3 , or $24 \mathrm{~h}$. Floating and trypsin-detached [0.25\% Trypsin in $0.53 \mathrm{mM}$ EDTA (Gibco)] cells were collected in 15-mL tubes, centrifuged at $1000 \mathrm{rpm}$ for $10 \mathrm{~min}$ in $4{ }^{\circ} \mathrm{C}$. Supernatant was discarded, and the cell pellet was re-suspended in $2 \mathrm{~mL}$ of $1 \times$ PBS. $20 \mu \mathrm{l}$ of suspension was mixed with equal volume of Trypan Blue (Cambrex) and transferred to a hemocytometer slide. Trypan blue exclusion was used to analyze viability of cells treated with different doses of plasma $\left(5,10,15,20\right.$, and $\left.30 \mathrm{~J} / \mathrm{cm}^{2}\right)$ at 1,3 , and $24 \mathrm{~h}$ after treatment. Viable cells exclude the dye, while nonviable cells uptake the dye and are stained. Total number of cells was normalized to $1(100 \%)$ to account for cell growth between the counting sessions: controls are set to $100 \%$, and cell viability is expressed as percent of control to allow for comparison between experiments.

\section{Colony Survival Assay}

$1 \times 10^{6}$ Melanoma cells were seeded in aluminum petri dishes 2 days before plasma treatment. Cells were exposed to $200 \mu \mathrm{M} \mathrm{H}_{2} \mathrm{O}_{2}$ (positive control) or plasma treated as described above at various doses. After treatment, fresh medium was added to the cells, and the cells were incubated for $24 \mathrm{~h}$ at $37^{\circ} \mathrm{C}$. After $24 \mathrm{~h}$, cells were trypsinized with $0.25 \%$ Tryspin in $0.53 \mathrm{mM}$ EDTA, centrifuged at $1000 \mathrm{rpm}$ for $5 \mathrm{~min}$, resuspended in $2 \mathrm{~mL}$ of $1 \times$ PBS, and quantified. Each sample was then was diluted to have 300 cells $/ \mathrm{mL}$, to start with the same number of cells for each treatment condition on day 0.300 cells $/ \mathrm{mL}$ were plated in $60 \mathrm{~mm}$ plastic petri dishes (plastic dishes were utilized to better enable us to count the colonies and as shown growth rates of cells in aluminum and plastic dishes were not significantly different) and then the cells were incubated for 11 days with the medium being replaced every 2 days. Assays were performed in triplicate.

\section{Annexin-V/PI Staining}

Cell propagation and plasma treatment were carried out as above. In order to confirm apoptotic activity, cells were cultured as above and then exposed to nonthermal plasma at a dose of either 5 or $15 \mathrm{~J} / \mathrm{cm}^{2}$. Untreated cells were used as control, while cells treated with Actinomycin D were used as positive control. The cells were harvested at 0, 24, 48, and $72 \mathrm{~h}$ after treatment and stained using the Guava Nexin apoptosis kit (Guava Technologies, Hayward CA). Analysis was performed using the Guava ${ }^{\circledR}$ Personal Cell Analysis (PCA) 96 System. Annexin-V is a calcium- dependent phospholipid binding protein with high affinity for phosphatidylserine (PS), a membrane component normally localized to the internal face 
of the cell membrane. Early in the apoptotic pathway, molecules of PS are translocated to the outer surface of the cell membrane where Annexin- $\mathrm{V}$ can readily bind them. This assay incorporates this PS-Annexin-V binding as an indicator of early-stage apoptotic cells. The Guava Nexin ${ }^{\mathrm{TM}}$ assay kit utilizes Annexin-V-PE to detect PS on the external membrane of apoptotic cells. The cell impermeable dye, 7-AAD, was used as an indicator of membrane structural integrity. 7-AAD is excluded from live, healthy cells, and early apoptotic cells, but permeates late-stage apoptotic and dead cells. Triplicate samples of each group were run consecutively at each time point to establish statistical validity. Annexin-V positive cells were quantified and plotted at each time point and each experimental condition.

\section{Caspase-3 Cleavage Assay}

Caspase- 3 cleavage was analyzed by immunoblot. Total cell lysates were prepared by direct lysis of floating and attached cells in $2 \times$ SDS sample buffer containing $\beta$-mercaptoethanol. Samples were electrophoresed on a $1.5-\mathrm{mm} 15 \%$ polyacrylamide gel at $150 \mathrm{~V}$ in Trisglycine SDS running buffer [ $25 \mathrm{mmol} / \mathrm{L}$ Tris, $192 \mathrm{mmol} / \mathrm{L}$ glycine, $0.1 \%$ SDS (pH 8.3)]. Following electrophoresis, proteins were transferred on to PVDF (Millipore, MA, USA) membrane for $3 \mathrm{~h}$ at $65 \mathrm{~V}$ in Tris-glycine transfer buffer [10\% SDS, Deionized Water, TrisGlycine and Methanol (VWR, PA USA)]. Immunoblotting was done by blocking membranes in 5\% bovine serum albumin (BSA, Fraction V, Fisher Scientific) in PBST for 30 min followed by incubation with primary antibody in 5\% BSA in PBST for cleaved caspase- 3 overnight for $10-12 \mathrm{~h}$ at $4{ }^{\circ} \mathrm{C}$ with rocking. Primary antibodies used for immunoblot included rabbit polyclonal antibodies specific for cleaved caspase-3 (Millipore, MA, USA). The primary antibody was detected with fluorescently tagged goat anti-rabbit Alexa and Fluor 488 (Santa Cruz Biotechnology). Immunoblot was developed using Odyssey Infrared Gel Imaging system (LI-COR Biosciences, NE, USA).

\section{TUNEL ${ }^{\circledR}$ Assay}

One of the hallmarks of late-stage apoptosis, or programmed cell death, is the fragmentation of nuclear chromatin. This generates DNA strands with exposed 3'-hydroxyl ends, which are enzymatically labeled in the TUNEL assay. Cells were harvested as above at 24, 48, and 72 $\mathrm{h}$ after treatment in triplicate and were stained using the DeadEnd ${ }^{\mathrm{TM}}$ Fluorometric TUNEL assay (Promega Co.). The DeadEnd ${ }^{\mathrm{TM}}$ Fluorometric TUNEL System is a classic TUNEL Assay designed for the specific detection and quantization of apoptotic cells within a cell population. The DeadEnd ${ }^{\mathrm{TM}}$ Fluorometric TUNEL System measures nuclear DNA fragmentation, an important biochemical hallmark of apoptosis in many cell types. The DeadEnd ${ }^{\mathrm{TM}}$ Fluorometric TUNEL System measures the fragmented DNA of apoptotic cells by catalytically incorporating fluorescein-12-dUTP( ${ }^{(a)}$ at $3^{\prime}-\mathrm{OH}$ DNA ends using the enzyme Terminal Deoxynucleotidyl Transferase (TdT), which forms a polymeric tail using the principle of the TUNEL (TdT-mediated dUTP Nick-End Labeling) assay. The fluorescein-12-dUTP-labeled DNA can then be visualized directly by fluorescence microscopy or quantitated by flow cytometry.

For fluorescence microscopy, cells were fixed on Lab-Tek slides for the TUNEL assay. Samples were analyzed under a fluorescence microscope using a standard fluorescence filter set to view the green fluorescence of Fluorescein at $520 \pm 20 \mathrm{~nm}$. Both control and treated cells were cultured in aluminum dishes to analyze the possibility of apoptosis developing from contact with aluminum.

For flow cytometry analysis, cell suspensions were treated with the DeadEndTM Fluorometric TUNEL System (Promega US Co), following the manufacturer's instructions. Counterstaining was done by incubating cells for $20 \mathrm{~min}$ at room temperature in the dark in phosphate-buffered saline containing $6 \mathrm{ng} / \mathrm{mL}$ RNAse (Roche Applies Sciences, 
Indianapolis, IN) and $5 \mathrm{ng} / \mathrm{mL}$ propidium iodide (Invitrogen, Carlsbad, CA) in PBS. Suspensions were washed once in PBS and resuspended in PBS for analysis. Flow cytometry was performed using a FACSORT flow cytometer (BD Biosciences, San Diego, CA). Data acquisition was done using Lysis II software (version 2.0, BD Biosciences). Fluorescence spillover was removed by compensation. At least 10,000 events were acquired per sample. Data analysis was performed using WinMDI software (Joseph Trotter, The Scripps Research Institute, La Jolla, CA, available online from http://www.facs.scripps.edu). Apoptotic and necrotic cells were differentiated by plotting PI fluorescence over fluorescein in a bivariate plot. Quadrants were set to define TUNEL-negative cells with normal DNA content; TUNEL-positive cells were counted as apoptotic, TUNEL-negative cells with lower DNA content as necrotic.

\section{Immunoblotting to Detect DNA Damage}

Protein expression and modification were analyzed by immunoblot. Total cell lysates were prepared by direct lysis of washed cells in $2 \times$ SDS sample buffer containing $5 \% \beta$ mercaptoethanol. Samples were electrophoresed at $150 \mathrm{~V}$ in Tris-glycine SDS running buffer [ $25 \mathrm{mmol} / \mathrm{L}$ Tris, $192 \mathrm{mmol} / \mathrm{L}$ glycine, $0.1 \% \mathrm{SDS}$ (pH 8.3)]. Following electrophoresis, proteins were transferred to PVDF membrane [(Millipore, MA, USA) for 2 $\mathrm{h}$ in Tris-glycine transfer buffer (10\% SDS, Deionized Water, Tris-Glycine and Methanol (VWR, PA USA)]. Immunoblotting was done by blocking membranes in $1 \%$ non-fat dried milk (Carnation) in PBS with 0.1\% Tween 20 (PBST) for $\alpha$-tubulin or 5\% bovine serum albumin (BSA, Fraction V, Fisher Scientific) in PBST for $\gamma$-H2AX, followed by incubation with primary antibodies overnight for $10-12 \mathrm{~h}$ at $4{ }^{\circ} \mathrm{C}$ with rocking. Primary antibodies used for immunoblot included mouse monoclonal antibodies specific for $\gamma$-H2AX [phosphohistone H2AX (serine 139), clone JBW301; Upstate] and $\alpha$-tubulin (Santa Cruz Biotechnology). The primary antibodies were detected with fluorescently tagged goat antimouse Alexa and Fluor 488 (Santa Cruz Biotechnology). Immunoblot was developed using Odyssey Infrared Gel Imaging system (LI-COR Biosciences, NE, USA).

\section{Statistics}

Statistical analyses were performed with Prism software (Graphpad, CA, USA). Data were normally distributed and expressed as the mean $\pm \mathrm{SD}$. Comparisons between two groups were analyzed by Student's $t$ test, and comparisons between more than two groups were analyzed by ANOVA. A value of $p \leq 0.05$ is considered statistically significant and is indicated in the text or in figures with a pound sign (\#). A value of $p \leq 0.001$ is indicated with an asterisk $(*)$.

\section{RESULTS}

\section{Cell Viability Post-Non-thermal Plasma Treatment Using Trypan Blue Staining}

Figure 3 a demonstrates short-term ( 1 and $3 \mathrm{~h}$ ) and long-term ( $24 \mathrm{~h}$ ) viability of melanoma cells exposed to non-thermal plasma at a dose of $5,10,20$, and $30 \mathrm{~J} / \mathrm{cm}^{2}$ as compared to untreated cells. Cell viability was analyzed by trypan blue exclusion test. A dose of $5 \mathrm{~J} / \mathrm{cm}^{2}$ reduced viability from $100 \%$ at $1 \mathrm{~h}$ to $80 \%$ at $3 \mathrm{~h}(p<0.001)$ and to $60 \%(p<0.001)$ at $24 \mathrm{~h}$ as compared to control. At a dose of $10 \mathrm{~J} / \mathrm{cm}^{2}$ viability dropped to $80 \%$ at 1 and $3 \mathrm{~h}(p<0.05)$ and to $50 \%(p<0.001)$ at $24 \mathrm{~h}$. Comparing untreated control cells to plasma-treated cells, we see that doses greater than $10 \mathrm{~J} / \mathrm{cm}^{2}$ induce significant loss of cell viability at 1,3 , and $24 \mathrm{~h}$ after treatment. A dose of $20 \mathrm{~J} / \mathrm{cm}^{2}$ yielded $60 \%(p<0.001)$ non-viable cells at 1 and $3 \mathrm{~h}$ which increased to $70 \%(p<0.001)$ at $24 \mathrm{~h}$. Cell viability decreased further when cells were treated at a dose of $30 \mathrm{~J} / \mathrm{cm}^{2}$ ranging from $80 \%$ non-viable cells at 1 and $3 \mathrm{~h}$ to more than $90 \%$ at $24 \mathrm{~h}$ as compared to control $(p<0.001)$. Since doses of 20 and $30 \mathrm{~J} / \mathrm{cm}^{2}$ decreased cell viability more than $50 \%$ at very short time points of 1 and $3 \mathrm{~h}$, it was decided to 
discontinue treating cells at doses higher than $15 \mathrm{~J} / \mathrm{cm}^{2}$. Higher doses were likely inducing significant necrosis that defeated the purpose of evaluating apoptotic activity in plasmatreated melanoma cells.

\section{Colony Survival Assays to Measure Long-Term Cell Viability Post-Non-thermal Plasma Treatment}

Trypan blue exclusion test gives a good indication of cell viability; however, it does not indicate true long-term survival that is better assessed by colony survival assay. In order to determine whether the decrease in cell number was due to induction of cell death and whether the remaining cells were viable, colony survival assays were performed at various time points after plasma treatment. Melanoma cell survival 11 days after plasma treatment was significantly decreased with increase in the dose as shown in Fig. 3b. Eleven days after treatment, only $28 \%$ survival was observed in cells treated at $5 \mathrm{~J} / \mathrm{cm}^{2}(p<0.001)$ which further decreased to 15 and $8 \%$ at 10 and $15 \mathrm{~J} / \mathrm{cm}^{2}$, respectively ( $p<0.001$ as compared to untreated cells). $230 \pm 12$ colonies were counted in untreated samples 11 days after plating. Non-thermal plasma not only impairs cell viability in the short term but also decreases longterm viability and survival of melanoma cells. This indicates that non-thermal plasma is not only able to kill melanoma cells but many of the cells that appear to survive are not viable, i.e., they cannot form a colony.

\section{Induction of Apoptosis in Melanoma Cells Post-Plasma Treatment Measured by Annexin-V/ PI Staining Via Flow Cytometry}

To confirm that non-thermal plasma was inducing apoptosis in melanoma cells, Annexin-V/ PI staining was utilized. The cells were treated with non-thermal plasma at two different doses, viz, 5 and $15 \mathrm{~J} / \mathrm{cm}^{2}$. The reason for limiting the treatment to these two doses was twofold, treatment of cells at a dose of 5 and $15 \mathrm{~J} / \mathrm{cm}^{2}$ decreased viability to 60 and $50 \%$, respectively, $24 \mathrm{~h}$ after plasma treatment and survivability decreased to 28 and $8 \%$, respectively, 11 days after treatment which meant we would be left with enough cells to analyze apoptotic activity after plasma treatment and doses higher than $15 \mathrm{~J} / \mathrm{cm}^{2}$ lead to significant necrosis. Untreated cells were used as control. Cells treated with 4-mM Actinomycin D, a known inducer of apoptosis, were used as positive control. The cells were analyzed 3, 24, 48, and $72 \mathrm{~h}$ after treatment. As shown in Fig. 4, Annexin-V/PI staining confirmed no significant increase in apoptosis at early time points $(3 \mathrm{~h})$ after non-thermal plasma treatment, but a significant increase in apoptosis was observed in plasma- treated cells 24,48 , and $72 \mathrm{~h}$ post-treatment $(p<0.001)$. As shown in Fig. $4,3 \mathrm{~h}$ after plasma treatment, the number of total apoptotic cells in untreated cells was $8 \%$, as compared with 12 and $10 \%$ after treatment with 5 and $15 \mathrm{~J} / \mathrm{cm}^{2}$, respectively. Twenty-four hours after treatment with 5 and $15 \mathrm{~J} / \mathrm{cm}^{2}$, the amount of Annexin-V/PI positive cells increased to 22 and $28 \%$, respectively $(p<0.001)$ as compared to untreated cells, which had only $8 \%$ apoptotic cells. $48 \mathrm{~h}$ after plasma treatment, total apoptotic cells in 5 and $15 \mathrm{~J} / \mathrm{cm}^{2}$ increased to 40 and $57 \%$, respectively ( $p<0.001)$ as compared to untreated control that had only $10 \%$ apoptotic cells. Seventy-two hours after plasma treatment, the total apoptotic cells were 42 and 50\% respectively $(p<0.001)$ in cells treated with 5 and $15 \mathrm{~J} / \mathrm{cm}^{2}$ as compared to $15 \%$ in untreated control. Thus, immediately following treatment with non-thermal plasma, there was no significant increase in Annexin- $\mathrm{V}$ positive cells. However, at later time points, nonthermal plasma induced significant apoptosis at 5 and $15 \mathrm{~J} / \mathrm{cm}^{2}$ as seen by the increase in Annexin- $\mathrm{V}$ positive cells.

\section{Caspase-3 Cleavage}

To test whether non-thermal plasma treatment of mammalian cells indeed led to induction of apoptosis by initiating caspase- 3 mediated apoptotic pathway, we determined cleavage of caspase- 3 post-non-thermal plasma treatment by carrying out western blot analysis of whole 
cell lysates collected at various time points after plasma treatment. As shown in Fig. 5a, no significant cleavage of caspase- 3 is observed up to $48 \mathrm{~h}$ after plasma treatment at a dose of 5 $\mathrm{J} / \mathrm{cm}^{2}$ while as shown in Fig. $5 \mathrm{~b}$ we see significant cleavage of caspase- $348 \mathrm{~h}$ after plasma treatment at a dose of $15 \mathrm{~J} / \mathrm{cm}^{2}$. Thus, non-thermal plasma induces cleavage of caspase- 3 in melanoma cancer cells that is a well-known marker for initiation of apoptosis.

\section{TUNEL ${ }^{\circledR}$ Assay}

To determine whether the decreased cell viability at a dose of $5 \mathrm{~J} / \mathrm{cm}^{2}$ as assessed by trypan blue staining (Fig. 3a) and colony survival (Fig. 3b) and early-stage apoptosis measured by Annexin-V/PI staining (Fig. 4) and initiation of apoptosis by caspase-3 cleavage (Fig. 5) led to late-stage apoptosis, terminal deoxyri-bonucleotide transferase-mediated nick-end labeling (TUNEL) assays were carried out in plasma-treated melanoma cells. As seen in the caspase- 3 cleavage assay, no cleavage of caspase- 3 was observed $48 \mathrm{~h}$ after plasma treatment at a dose of $5 \mathrm{~J} / \mathrm{cm}^{2}$ whereas significant cleavage was observed after treatment at a dose of $15 \mathrm{~J} / \mathrm{cm}^{2}$, we decided to perform TUNEL analysis only on cells exposed to a dose of $15 \mathrm{~J} / \mathrm{cm}^{2}$. Cells were treated at a dose of $15 \mathrm{~J} / \mathrm{cm}^{2}$ and then incubated and stained for DNA fractionation $24 \mathrm{~h}$ later. Following the TUNEL assay procedure, it was observed that a significant percentage of these cells exhibit apoptotic behavior as is evident in Figs. 6a and $6 \mathrm{~b}$. The number of TUNEL-positive cells (indicative of fragmented DNA) after treatment was significantly increased in cells treated with non-thermal plasma at a dose of $15 \mathrm{~J} / \mathrm{cm}^{2}$. The results of the flow cytometry tests performed 24,48 , and $72 \mathrm{~h}$ following treatment are presented as a representative in Fig. 6c. As shown in Fig. 6d, apoptosis develops $24 \mathrm{~h}$ following treatment, where $25.5 \%$ of cells are present in the treated group, compared with $2.2 \%$ in the control group $(p<0.001)$. As time progresses, even more cells undergo apoptosis, further reaching $72.8 \%$ of apoptotic cells in the treatment group versus $10 \%$ in the control group $72 \mathrm{~h}$ following treatment $(p<0.001)$. This indicates that non-thermal plasma treatment induces apoptosis $24 \mathrm{~h}$ after plasma treatment and cells continue to die long after plasma treatment. TUNEL-positive cells result from fragmentation of the nuclear chromatin, a hallmark of cells in the late stages of apoptosis.

\section{Role of Change in pH of Medium in Non-thermal Plasma-Mediated Melanoma Cell Death}

It is known that non-thermal plasma treatment of cell culture medium leads to significant reduction of $\mathrm{pH}$ and this may be a cause for the observed cell death. As shown in Fig. 7a, plasma treatment of cell culture medium leads to drop in $\mathrm{pH}$ from 8.5 to 5.5 with increasing doses of plasma from 5 to $30 \mathrm{~J} / \mathrm{cm}^{2}$. pH of the medium drops to 6.5 in samples treated at a dose of $20 \mathrm{~J} / \mathrm{cm}^{2}$ ( $p<0.05$ as compared to untreated sample) and drops further to 5.4 in samples treated at a dose of $30 \mathrm{~J} / \mathrm{cm}^{2}(p<0.001$ as compared to untreated sample). To test the role of significant change in $\mathrm{pH}$ post-plasma treatment as a mediator of plasma-induced cell death, plasma treatment of cells at a dose of 15 and $30 \mathrm{~J} / \mathrm{cm}^{2}$ was compared to incubation of melanoma cells in acidified medium ( $\mathrm{pH}$ 5.4) for $1 \mathrm{~min}$ followed by incubation in fresh medium for $3 \mathrm{~h}$. As shown in Fig. $7 \mathrm{~b}, 3 \mathrm{~h}$ after plasma treatment, the number of dead cells in plasma-treated $\left(15\right.$ and $30 \mathrm{~J} / \mathrm{cm}^{2}$ ) samples is significantly higher (50 and $78 \%$, respectively; $p<0.001)$ than those in untreated control $(8 \%)$ or cells placed in acidified medium (10\%). Based on these results, change of $\mathrm{pH}$ of the medium after plasma treatment does not play a significant role in plasma-induced apoptosis.

\section{Role of Non-thermal Plasma Produced ROS in the Induction of Apoptosis in Melanoma Cells}

Non-thermal plasma is known to produce various active neutral short- and long-living ROS like $[\mathrm{OH}, \mathrm{O}$, electronically excited oxygen $\mathrm{O}(1 \mathrm{D}), \mathrm{O} 2(1 \Delta \mathrm{g})]$ and $\left(\mathrm{O}_{3}, \mathrm{HO}_{2}, \mathrm{H}_{2} \mathrm{O}_{2}\right)$ in cell culture medium. ${ }^{24,28}$ To test the role of these ROS in non-thermal plasma-induced apoptosis, we pre-incubated melanoma cells for $1 \mathrm{~h}$ in $2.25 \mathrm{mM} \mathrm{NAC}$, an intracellular 
scavenger of ROS, followed by treatment at a dose of 5 and $15 \mathrm{~J} / \mathrm{cm}^{2}$. Apoptotic activity was assayed $24 \mathrm{~h}$ post-plasma treatment using Annexin-v/PI staining. Untreated cells and untreated cells with NAC alone were used as controls, and cells treated at the same dose in the absence of NAC were used as positive control. As shown in Fig. 7c, pre-treatment with $2.25 \mathrm{mM}$ NAC, a free radical scavenger, significantly decreased the level of apoptosis induced in response to plasma treatment as compared to cells without NAC. Plasma treatment at a dose of 5 and $15 \mathrm{~J} / \mathrm{cm}^{2}$ induced apoptosis in 28 and $35 \%$ of the cells, respectively, which was reduced to $11 \%(p<0.001)$ and $20 \%(p<0.05)$, respectively, in cells pre-treated with NAC, while NAC alone had no effect on the melanoma cells. These results indicate that ROS generated by non-thermal plasma are likely mediating non-thermal plasma-induced apoptosis.

\section{Induction of DNA Damage in Melanoma Cells by Plasma-Produced ROS}

One possible mechanism underlying the observed ROS-mediated apoptotic effects of DBD plasma is induction of massive DNA damage. ${ }^{41}$ To determine whether DBD plasma treatment of melanoma cells could induce DNA damage, we looked at phosphorylation of $\mathrm{H} 2 \mathrm{AX}$, a histone variant that is phosphorylated in response to DNA damage ${ }^{55}$ Western blot with an antibody that detects H2AX phosphorylated at Ser139 $(\gamma$-H2AX) revealed that plasma treatment of cells at doses ranging from 5 to $30 \mathrm{~J} / \mathrm{cm}^{2}$ induces a dose-dependent increase in $\gamma-\mathrm{H} 2 \mathrm{AX}$ (Fig. 8a). It is important to note that the $\gamma-\mathrm{H} 2 \mathrm{AX}$ signal deteriorates at $30 \mathrm{~J} / \mathrm{cm}^{2}$ indicating the cells are dying via necrosis and not apoptosis. This may be another indication that at higher doses $\left(>15 \mathrm{~J} / \mathrm{cm}^{2}\right)$ non-thermal plasma may induce necrosis.

To determine whether DNA damage is induced by plasma-generated intracellular ROS, we pre-incubated melanoma cells for $2 \mathrm{~h}$ with $4 \mathrm{mM}$ NAC, washed the cells with $1 \times \mathrm{PBS}$, followed by plasma treatment. NAC completely blocked the induction of $\gamma$-H2AX (DNA damage) (Fig. 8b) in melanoma cells at a dose of $15 \mathrm{~J} / \mathrm{cm}^{2}$, suggesting that the accumulation of DNA damage, as measured by $\gamma-\mathrm{H} 2 \mathrm{AX}$, is mediated by intracellular ROS and DBD plasma-induced DNA damage may play a major role in the observed plasma-induced apoptosis.

\section{DISCUSSION}

Initiation of apoptosis is an important issue in cancer treatment as cancer cells frequently have acquired the ability to block apoptosis and thus are more resistant to chemotherapeutic drugs. Targeted and selective destruction of cancer cells is desirable for many reasons, ranging from the enhancement of or aid to current medical methods to problems currently lacking a solution, e.g., lung cancer. In this article, we demonstrate the induction of apoptosis in a human melanoma cell line in vitro by exposure to non-thermal atmospheric pressure plasma and try to present some of the underlying biological mechanisms.

The melanoma cell line (ATCC 2058) was chosen as our model because they are very rapidly proliferating and adherent. We did not aim to find a de novo treatment for melanoma, but rather investigate the influence of the non-thermal DBD plasma on human cancer cells. Initial experiments began by identifying the characteristics of a sub-lethal dose. This is the dose where we observed the ability of DBD plasma to induce apoptosis but not significant necrosis. We went on to follow the effects of this exposure on cell death over time. Apoptotic activity in melanoma cells was evaluated using standard approaches including trypan blue staining, Annexin-V/PI, caspase-3 cleavage, and TUNEL assay.

Non-thermal plasma was shown to induce apoptosis in melanoma cells at a dose of $5 \mathrm{~J} / \mathrm{cm}^{2}$ or higher. During apoptosis, cells undergo a series of complex biochemical changes leading to cell death without causing significant inflammation. The fact that treated cells do not 
initially die but stop growth and die en masse 12-24 h following treatment, while untreated cells continue to grow and proliferate, suggested that plasma treatment might induce apoptosis. Early apoptotic behavior was confirmed with Annexin-V/PI and Caspase-3 cleavage assays, while late apoptotic behavior was confirmed through TUNEL staining with subsequent flow cytometry.

Previously, $\mathrm{we}^{14}$ and other groups ${ }^{18,35,40,57,61,64,65,67,69,72}$ have shown that plasma is able to destroy cells; however, it was also observed that plasma might be able to initiate or catalyze some biochemical processes in biological systems. ${ }^{14,22-24,26,27}$ Cell death after treatment of melanoma cells with non-thermal plasma occurs via the apoptotic pathway. The cell death mechanism post-plasma treatment in vivo or in vitro is an important consideration. Apoptosis is a mode of programmed cell death initiated by physiological or pathological signals. Apoptotic cells are broken up into apoptotic bodies, which are engulfed by neighboring cells leading to a clean cell death without significant inflammatory response. ${ }^{7,21,44}$ On the contrary, necrosis is a form of accidental cell death accompanied by cellular swelling, blebbing, and increased membrane permeability leading to leakage of cytosolic content. This typically leads to inflammation in the surrounding tissue. ${ }^{7,21,44}$ There is significant therapeutic advantage in cancer treatment to kill cells by apoptosis and avoid necrosis and the associated inflammation. By controlling plasma dose, it should be possible to use plasma to primarily induce apoptosis rather than necrosis.

By acidifying the media, it was shown that the plasma treatment initiates this behavior in cells not through a pH change in the growth media or through interaction with the aluminum dishes, but through direct interaction with the cells. Pre-incubation of melanoma cells with $2.25 \mathrm{mM}$ NAC significantly reduced the amount of apoptosis as compared to untreated control or cells without NAC. This indicates that induction of apoptosis by DBD plasma is mediated through the formation of intracellular ROS. Non-thermal plasmas produce longlived $\left(\mathrm{O}_{3}, \mathrm{NO}, \mathrm{HO}_{2}, \mathrm{H}_{2} \mathrm{O}_{2}\right)$ and short-lived [OH, O, electronically excited $\mathrm{O}(1 \mathrm{D}), \mathrm{O} 2$ $(1 \Delta \mathrm{g})]$ neutral particles and charged particles (ions and electrons). Both charged and neutral particles can lead to additional ROS production in the treated fluid. ${ }^{24,28}$ Direct effects of non-thermal plasma treatment could include local heating caused by plasma streamers or UV radiation. Non-thermal atmospheric pressure DBD plasma is able to produce a large concentration of ROS in the extracellular media during treatment. ${ }^{9}$ Interestingly, the intracellular ROS scavenger NAC decreased induction of apoptosis in melanoma cells after plasma treatment. ROS produced by plasma extracellularly may move across the cell membrane by active transport across the bilayer, transient opening of pores in the membrane, or activation of signaling pathways that modify intracellular ROS concentration. ROS produced by non-thermal plasma may also modify the cell media, which in turn may initiate intracellular processes. Since many of these ROS species have a very short life span, they may immediately interact with components of the medium including amino acids and proteins, leading to production of long-lived reactive organic hydroperoxides. ${ }^{16}$ These in turn may induce lipid peroxidation and cell membrane damage, or they may bind to cell membrane receptors and activate intracellular signaling pathways leading to apoptosis. Various studies have shown that intracellular ROS can induce apoptosis in a caspase-3 dependent manner. ${ }^{31,53,70,71}$ As result of the above-mentioned processes, intracellular ROS may damage cellular DNA leading to apoptosis due to inability of the cells to repair the massive damage. As shown in Fig. 8a, melanoma cells undergo DNA damage due to nonthermal plasma treatment as measured by phosphorylation of H2AX. Interestingly, the intracellular ROS scavenger, NAC, also blocked phosphorylation of H2AX after nonthermal plasma treatment of melanoma cells, indicating that the induction of DNA damage is mediated through the formation of intracellular ROS and the inability of the cells to repair the induced DNA damage may ultimately lead to induction of apoptosis as observed. 
Ionizing radiation $1,56,63$ and chemotherapy $6,8,45$ are the most commonly used treatments for various types of malignancies, including melanoma, but both treatment modalities have severe systemic side effects since they not only kill the tumor but also damage healthy tissue surrounding the malignant tissue. Melanoma is the most aggressive form of skin cancer and is notoriously resistant to radiation and chemotherapy. Recently, pulsed electric fields have also been shown to be able to initiate apoptosis in melanoma cancer cells. ${ }^{46}$ Non-thermal plasma differs from radiation, chemotherapy, and electromagnetic fields; chemotherapy has systemic side effects while electromagnetic fields are penetrating and therefore injure surrounding tissue. Ionizing radiation requires extensive and expensive equipment for administration. Various studies also suggest that melanoma cells frequently acquire radiation resistance ${ }^{47}$ and chemoresistance ${ }^{62}$ by exploiting their intrinsic resistance to apoptosis and by reprogramming their proliferation and survival pathways during melanoma progression. Non-thermal plasma on the other hand provides a novel and safer means to induce apoptosis since it is non-penetrating and therefore provides precise control of treatment area and depth. Non-thermal plasma has the potential benefit that it may be applied directly to specific areas of interest potentially avoiding systemic side effects. Since non-thermal plasma can be attached to the end of a probe, it has the added benefit of potentially being able to target areas of the body that are technically difficult to reach such as the lungs and internal organs. Non-thermal plasma devices are also relatively inexpensive, portable, and simple to manufacture and operate. Based on its ability to produce apoptosis in melanoma cancer cells, non-thermal plasma could potentially be used as a novel clinical cancer therapy tool.

We have demonstrated that exposure of melanoma cells to atmospheric pressure nonthermal DBD plasma induces apoptosis, and this effect is likely related to production of ROS by non-thermal plasma and DNA damage induced due to intracellular ROS. From the results presented here, it is clear that the dose of plasma can be regulated and can be administered at doses that appear to induce apoptosis in cells to an equal or greater degree than a known inducer of apoptosis. It is important to separate the effects of individual constituents of plasma in direct contact with cells, as well as to study synergistic effects of different plasma components to obtain further insight into mechanisms of induction of apoptosis. Future work will primarily address understanding the interaction of plasma with living tissue and physical and biochemical mechanisms thereof; for example, evaluation of the effect of various plasma-generated excited species on the cell membrane and membrane proteins or intracellular signaling due to production of ROS by nonthermal plasma. Further investigations are warranted to evaluate the detailed biological mechanisms by which nonthermal plasma can induce apoptosis. A better understanding of biological pathways/ mechanisms of non-thermal plasma mediated apoptosis, as well as its selectivity, will facilitate the introduction of this modality as an additional resource in our anticancer treatment arsenal.

\section{Acknowledgments}

We would like to acknowledge Monica Jost for her help and guidance with the TUNEL assay and Dr. Christian Sell for allowing us to use his flow cytometer to carry out the Annexin-V/PI assay.

\section{References}

1. Berk LB. Radiation therapy as primary and adjuvant treatment for local and regional melanoma. Cancer Control. 2008; 15(3):233-238. [PubMed: 18596675]

2. Colt HG, Crawford SW. In vitro study of the safety limits of bronchoscopic argon plasma coagulation in the presence of airway stents. Respirology. 2006; 11(5):643-647. [PubMed: 16916340] 
3. Coulombe, S. Live cell permeabilization using the APGD-t. 1st International Conference on Plasma Medicine (ICPM); TX: Corpus Christi; 2007.

4. Coulombe S, et al. Miniature atmospheric pressure glow discharge torch (APGD-t) for local biomedical applications. Pure Appl Chem. 2006; 78(6):1137-1146.

5. Eliasson B, Egli W, Kogelschatz U. Modelling of dielectric barrier discharge chemistry. Pure Appl Chem. 1994; 66(6):1275-1286.

6. Eton O. Chemotherapy, cytokines, and biochemotherapy for melanoma. Cancer Chemother Biol Response Modif. 2005; 22:739-748. [PubMed: 16110637]

7. Fiers W, et al. More than one way to die: apoptosis, necrosis and reactive oxygen damage. Oncogene. 1999; 18(54):7719-7730. [PubMed: 10618712]

8. Flaherty KT. Chemotherapy and targeted therapy combinations in advanced melanoma. Clin Cancer Res. 2006; 12(Pt 2):2366-2370.

9. Fridman, A. Plasma Chemistry. New York, NY: Cambridge University Press; 2008. Plasma biology and plasma medicine; p. 848-857.

10. Fridman, A. Plasma Chemistry. New York, NY: Cambridge University Press; 2008.

11. Fridman, A. Plasma Biology and Plasma Medicine. New York: Cambridge University Press; 2008.

12. Fridman A, Chirokov A, Gutsol A. Non-thermal atmospheric pressure discharges. J Phys D: Appl Phys. 2005; 38:R1-R24.

13. Fridman, A.; Kennedy, LA. Plasma Physics and Engineering. New York: Routledge; 2004. p. 853

14. Fridman G, et al. Blood coagulation and living tissue sterilization by floating-electrode dielectric barrier. Disch Air Plasma Chem Plasma Process. 2006; 26(4):425-442.

15. Fridman G, et al. Comparison of direct and indirect effects of non-thermal atmospheric-pressure plasma on bacteria. Plasma Process Polym. 2007; 4(4):370-375.

16. Gebicki S, Gebicki JM. Formation of peroxides in amino acids and proteins exposed to oxygen free radicals. Biochem J. 1993; 289(Pt 3):743-749. [PubMed: 8435071]

17. Ginsberg GG, et al. The argon plasma coagulator: February 2002. Gastrointest Endosc. 2002; 55(7):807-810. [PubMed: 12024132]

18. Goree J, Bin L, Drake D, Stoffels E. Killing of $S$. mutans bacteria using a plasma needle at atmospheric pressure. IEEE Trans Plasma Sci. 2006; 34(4):1317-1324.

19. Gostev, V.; Dobrynin, D. Medical microplasmatron. 3rd International Workshop on Microplasmas (IWM- 2006); Greifswald, Germany. 2006.

20. Hu W, Kavanagh JJ. Anticancer therapy targeting the apoptotic pathway. Lancet Oncol. 2003; 4(12):721-729. [PubMed: 14662428]

21. Jaattela M. Programmed cell death: many ways for cells to die decently. Ann Med. 2002; 34(6): 480-488. [PubMed: 12523503]

22. Kalghatgi, S., et al. NATO Advanced Study Institute on Plasma Assisted Decontamination of Biological and Chemical Agents. Cesme-Izmir, Turkey: Springer; 2007. Applications of non thermal atmospheric pressure plasma in medicine.

23. Kalghatgi S, et al. Mechanism of blood coagulation by nonthermal atmospheric pressure dielectric barrier discharge plasma. IEEE Trans Plasma Sci. 2007; 35(5):1559-1566.

24. Kalghatgi, S., et al. Penetration of direct non-thermal plasma treatment into living cells. IEEE 35th International Conference on Plasma Science; Karlsruhe, Germany. 2008.

25. Kalghatgi, S., et al. Toxicity analysis of direct non-thermal plasma treatment of living tissue. IEEE 35th International Conference on Plasma Science; Karlsruhe, Germany. 2008.

26. Kalghatgi, S., et al. Toxicity of non-thermal plasma treatment of endothelial cells. IEEE 35 th International Conference on Plasma Science; Karlsruhe, Germany. 2008.

27. Kalghatgi, SU., et al. Non-thermal dielectric barrier discharge plasma treatment of endothelial cells. 30th Annual International Conference of the IEEE Engineering in Medicine and Biology Society; Vancouver, BC, Canada: Inst. of Elec. and Elec. Eng. Computer Society; 2008.

28. Kalghatgi, S., et al. On the interaction of non-thermal atmospheric pressure plasma with tissues. Proceedings of the IEEE 17th International Pulsed Power Conference; Washington, DC. 2009. 
29. Kalghatgi, S., et al. Toxicity of direct non-thermal atmospheric pressure plasma treatment of living tissue. Proceedings of the IEEE 17th International Pulsed Power Conference; Washington DC. 2009.

30. Kalghatgi S, et al. Endothelial cell proliferation is enhanced by low dose non-thermal plasma through fibroblast growth factor-2 release. Ann Biomed Eng. 2010; 38(3):748- 757. [PubMed: 20013154]

31. Kawiak A, et al. Induction of apoptosis by plumbagin through reactive oxygen species-mediated inhibition of topoisomerase II. Toxicol Appl Pharmacol. 2007; 223(3):267-276. [PubMed: 17618663]

32. Kieft IE, Kurdi M, Stoffels E. Reattachment and apoptosis after plasma-needle treatment of cultured cells. IEEE Trans Plasma Sci. 2006; 34(4):1331-1336.

33. Kieft IE, et al. Plasma treatment of mammalian vascular cells: a quantitative description. IEEE Trans Plasma Sci. 2005; 33(2):771-775.

34. Kogelschatz, U., et al. Plasma Physics. 1. London: Taylor \& Francis; 2004. Non-Equilibrium Air Plasmas at Atmospheric Pressure.

35. Kuo SP, Tarasenko O, Popovic S, Levon K. Killing of bacterial spores contained in a paper envelope by a microwave plasma torch. IEEE Trans Plasma Sci. 2006; 34(4):1275-1280.

36. Laroussi M. Low temperature plasma-based sterilization: overview and state-of-the-art. Plasma Process Polym. 2005; 2:391-400.

37. Laroussi M, Alexeff I, Kang WL. Biological decontamination by nonthermal plasmas. IEEE Trans Plasma Sci. 2000; 28(1):184-188.

38. Laroussi M, Leipold F. Evaluation of the roles of reactive species, heat, and UV radiation in the inactivation of bacterial cells by air plasmas at atmospheric pressure. Int J Mass Spectrom. 2004; 233(1-3):81-86.

39. Laroussi M, Mendis DA, Rosenberg M. Plasma interaction with microbes. New J Phys. 2003; 5:41.1-41.10.

40. Laroussi M, et al. Inactivation of bacteria by the plasma pencil. Plasma Process Polym. 2006; 3(67):470-473.

41. Lehnert BE, Iyer R. Exposure to low-level chemicals and ionizing radiation: reactive oxygen species and cellular pathways. Hum Exp Toxicol. 2002; 21(2):65-69. [PubMed: 12102498]

42. Léveillé V, Coulombe S. Design and preliminary characterization of a miniature pulsed RF APGD torch with downstream injection of the source of reactive species. Plasma Sources Sci Technol. 2005; 14:467-476.

43. Lord MJ, Maltry JA, Shall LM. Thermal injury resulting from arthroscopic lateral retinacular release by electrocautery: report of three cases and a review of the literature. Arthroscopy. 1991; 7(1):33-37. [PubMed: 2009116]

44. Majno G, Joris I. Apoptosis, oncosis, and necrosis. An overview of cell death. Am J Pathol. 1995; 146(1):3-15. [PubMed: 7856735]

45. Mandara M, et al. Chemotherapy for metastatic melanoma. Expert Rev Anticancer Ther. 2006; 6(1):121-130. [PubMed: 16375649]

46. Nuccitelli R, et al. A new pulsed electric field therapy for melanoma disrupts the tumor's blood supply and causes complete remission without recurrence. Int J Cancer. 2009; 125(2):438-445. [PubMed: 19408306]

47. Pak BJ, et al. Radiation resistance of human melanoma analysed by retroviral insertional mutagenesis reveals a possible role for dopachrome tautomerase. Oncogene. 2004; 23(1):30-38. [PubMed: 14712208]

48. Porter KA, et al. Electrocautery as a factor in seroma formation following mastectomy. Am J Surg. 1998; 176(1):8-11. [PubMed: 9683123]

49. Puhlev I, et al. Desiccation tolerance in human cells. Cryobiology. 2001; 42(3):207-217. [PubMed: 11578120]

50. Raiser J, Zenker M. Argon plasma coagulation for open surgical and endoscopic applications: state of the art. J Phys D: Appl Phys. 2006; 39(16):3520. 
51. Rappaport WD, et al. Effect of electrocautery on wound healing in midline laparotomy incisions. Am J Surg. 1990; 160(6):618-620. [PubMed: 2147542]

52. Rath PC, Aggarwal BB. TNF-induced signaling in apoptosis. J Clin Immunol. 1999; 19(6):350364. [PubMed: 10634209]

53. Ratha J, et al. Attenuated Leishmanial sphingolipid induces apoptosis in A375 human melanoma cell via both caspase-dependent and -independent pathways. Mol Cell Biochem. 2007; 304(1-2): 143-154. [PubMed: 17530191]

54. Reed JC. Apoptosis-based therapies. Nat Rev Drug Discov. 2002; 1(2):111-121. [PubMed: 12120092]

55. Rogakou E, et al. DNA double-stranded breaks induce histone $\mathrm{H} 2 \mathrm{AX}$ phosphorylation on serine 139. J Biol Chem. 1998; 273:5858-5868. [PubMed: 9488723]

56. Schild SE. Role of radiation therapy in the treatment of melanoma. Expert Rev Anticancer Ther. 2009; 9(5):583-586. [PubMed: 19445575]

57. Sharma A, Pruden A, Stan O, Collins GJ. Bacterial inactivation using an RF-powered atmospheric pressure plasma. IEEE Trans Plasma Sci. 2006; 34(4)

58. Shekhter AB, et al. Beneficial effect of gaseous nitric oxide on the healing of skin wounds. Nitric Oxide Biol Chem. 2005; 12(4):210-219.

59. Siemens CW. On the electrical tests employed during the construction of the Malta and Alexandria telegraph, and on insulating and protecting submarine cables. J Frankl Inst. 1862; 74(3):166-170.

60. Simmons PD, Langlet F, Thin RN. Cryotherapy versus electrocautery in the treatment of genital warts. Br J Vener Dis. 1981; 57(4):273-274. [PubMed: 7272706]

61. Sladek REJ, Stoffels E. Deactivation of Escherichia coli by the plasma needle. J Phys D: Appl Phys. 2005; 38:1716-1721.

62. Soengas MS, Lowe SW. Apoptosis and melanoma chemoresistance. Oncogene. 2003; 22(20): 3138-3151. [PubMed: 12789290]

63. Stevens G, Hong A. Radiation therapy in the management of cutaneous melanoma. Surg Oncol Clin N Am. 2006; 15(2):353-371. [PubMed: 16632220]

64. Stoffels E. Gas plasmas in biology and medicine. J Phys D: Appl Phys. 2006; 39(16)

65. Stoffels E, et al. Plasma needle for in vivo medical treatment: recent developments and perspectives. Plasma Sources Sci Technol. 2006; 15(4):S169-S180.

66. Stoffels, E., et al. Cold gas plasma in biology and medicine. In: d'Agostino, R., editor. Advanced Plasma Technology. Weinheim; Wiley-VCH: 2008. p. 301-318.

67. Tarasenko O, Nourbakhsh S, Kuo SP, Bakhtina A, Alusta P, Kudasheva D, Cowman M, Levon K. Scanning electron and atomic force microscopy to study plasma torch effects on B. cereus Spores. IEEE Trans Plasma Sci. 2006; 34(4):1281-1289.

68. Vargo JJ. Clinical applications of the argon plasma coagulator. Gastrointest Endosc. 2004; 59(1): 81-88. [PubMed: 14722558]

69. Williamson JM, Trump DD, Bletzinger P, Ganguly BN. Comparison of high-voltage ac and pulsed operation of a surface dielectric barrier discharge. J Phys D: Appl Phys. 2006; 39:4400-4406.

70. Yang J, Su Y, Richmond A. Antioxidants tiron and $N$-acetyl-L-cysteine differentially mediate apoptosis in melanoma cells via a reactive oxygen species-independent NF-kappaB pathway. Free Radic Biol Med. 2007; 42(9):1369-1380. [PubMed: 17395010]

71. Zafarullah M, et al. Molecular mechanisms of $N$-acetyl-cysteine actions. Cell Mol Life Sci. 2003; 60(1):6-20. [PubMed: 12613655]

72. Zhang R, Wang L, Wu Y, Guan Z, Jia Z. Bacterial decontamination of water by bipolar pulsed discharge in a gas; liquid; solid three-phase discharge reactor. IEEE Trans Plasma Sci. 2006; 34(4):1370-1374. 

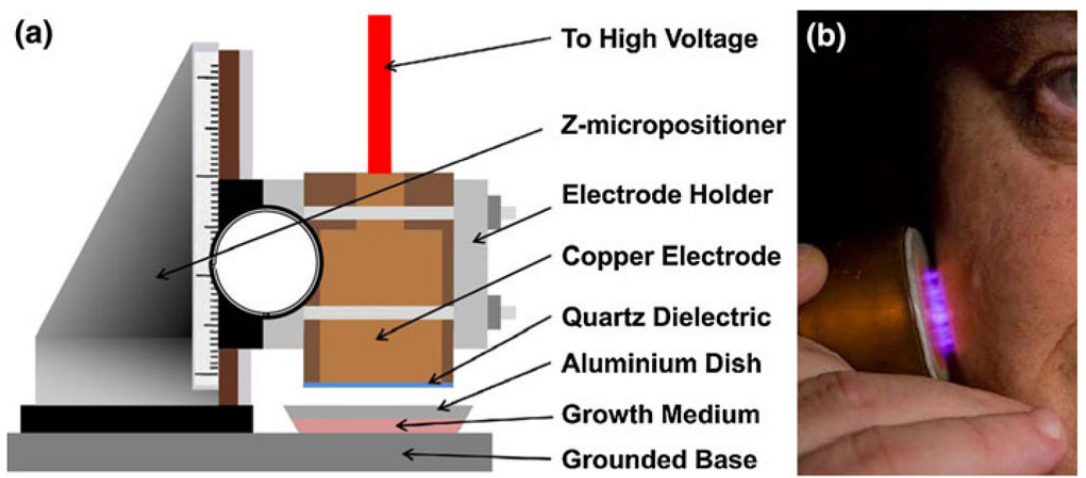

FIGURE 1.

Non-thermal plasma treatment of melanoma cells. (a) Schematic of the non-thermal atmospheric pressure DBD plasma treatment setup showing the high voltage electrode and the sample holder. Note: The depth of medium covering the cells has been exaggerated for visual clarity, but the actual depth is a few $100 \mu \mathrm{m}$. (b) Non-thermal atmospheric pressure DBD plasma applied safely to human tissue. 


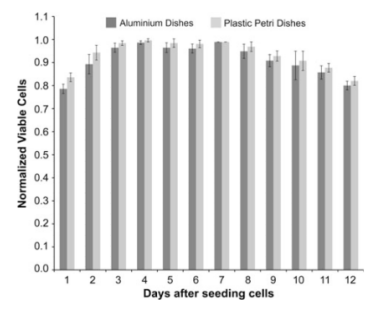

FIGURE 2.

Growth rates of melanoma cells in poly L-lysine coated dishes and plastic petri dishes. $1 \times$ $10^{6}$ cells were seeded at day 0 in aluminum and plastic petri dishes. Viability was evaluated using trypan blue exclusion test each day for 12 days after seeding. Data from triplicate samples $( \pm \mathrm{SD})$ were plotted. Growth was monitored by replacing medium every 2 days. 


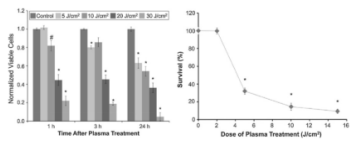

FIGURE 3.

Non-thermal DBD plasma treatment leads to dose-dependent decrease in viability and survivability of melanoma cells. (a) Melanoma cells were exposed to non-thermal DBD plasma at the indicated doses. Cell viability was analyzed 1,3 , and $24 \mathrm{~h}$ after plasma treatment by trypan blue exclusion test. Briefly, floating and trypsin-detached cells were centrifuged and resuspended in 2-mL PBS. 20- $\mu \mathrm{L}$ cell suspension was mixed with $20-\mu \mathrm{L}$ trypan blue and incubated for $5 \mathrm{~min}$ at room temperature. Viable and non-viable cells were counted on a hemocytometer. Data from triplicate samples $( \pm \mathrm{SD})$ are expressed relative to total number of cells in untreated control. (b) Cells were treated with the indicated dose of DBD plasma; and colony survival assays were performed as described. Data from triplicate samples $( \pm \mathrm{SD})$ are expressed relative to the number of colonies in the untreated control. 


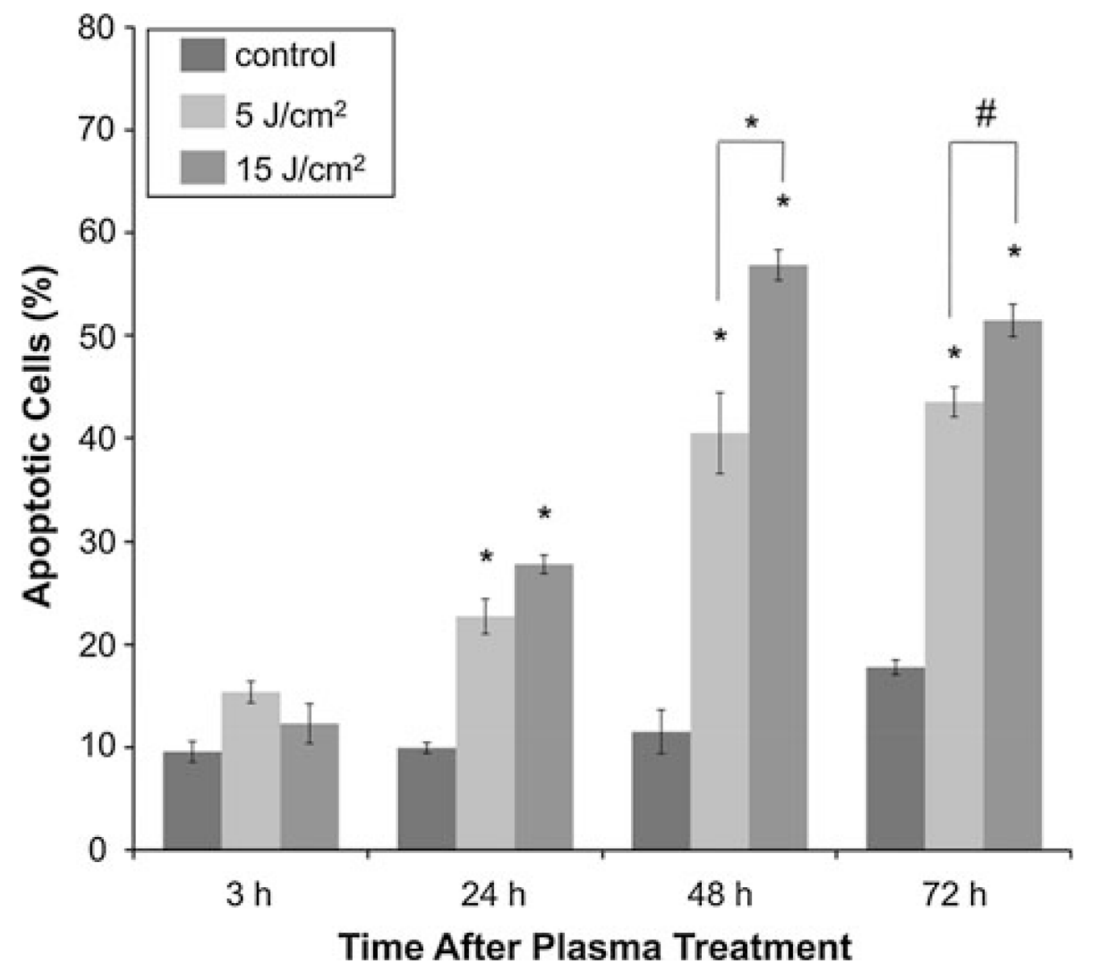

FIGURE 4.

Early apoptotic activity in melanoma cells after non-thermal plasma treatment is confirmed by Annexin-V/PI staining. Apoptotic activity in plasma-treated melanoma cells was analyzed 3, 24, and $72 \mathrm{~h}$ after treatment with the indicated dose of DBD plasma, by harvesting and staining cells with Annexin-V/propidium iodide (PI) according to the manufacturer's protocol. Samples were run on Guava ${ }^{\circledR}$ flow cytometer and analyzed by Guava $^{\circledR}$ flow cytometry software. Data from triplicate samples $( \pm$ SD) are plotted. 

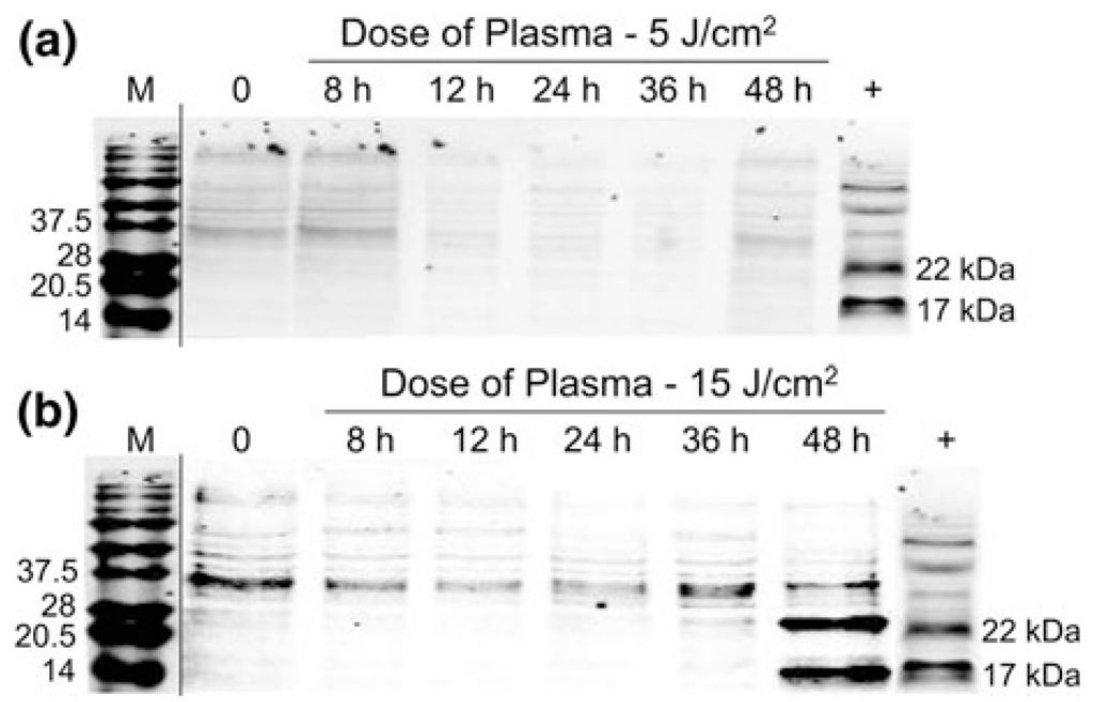

FIGURE 5.

Caspase- 3 cleavage assay confirms that nonthermal plasma treatment initiates apoptosis in melanoma cells. Melanoma cells were treated with non-thermal plasma at two different doses, (a) $5 \mathrm{~J} / \mathrm{cm}^{2}$ and (b) $15 \mathrm{~J} / \mathrm{cm}^{2}$. Caspase- 3 cleavage was analyzed by preparing lysates $8,12,24,36$, and $48 \mathrm{~h}$ after plasma treatment by immunoblot. Representative immunoblots with antibody to cleaved caspase- 3 are shown. 

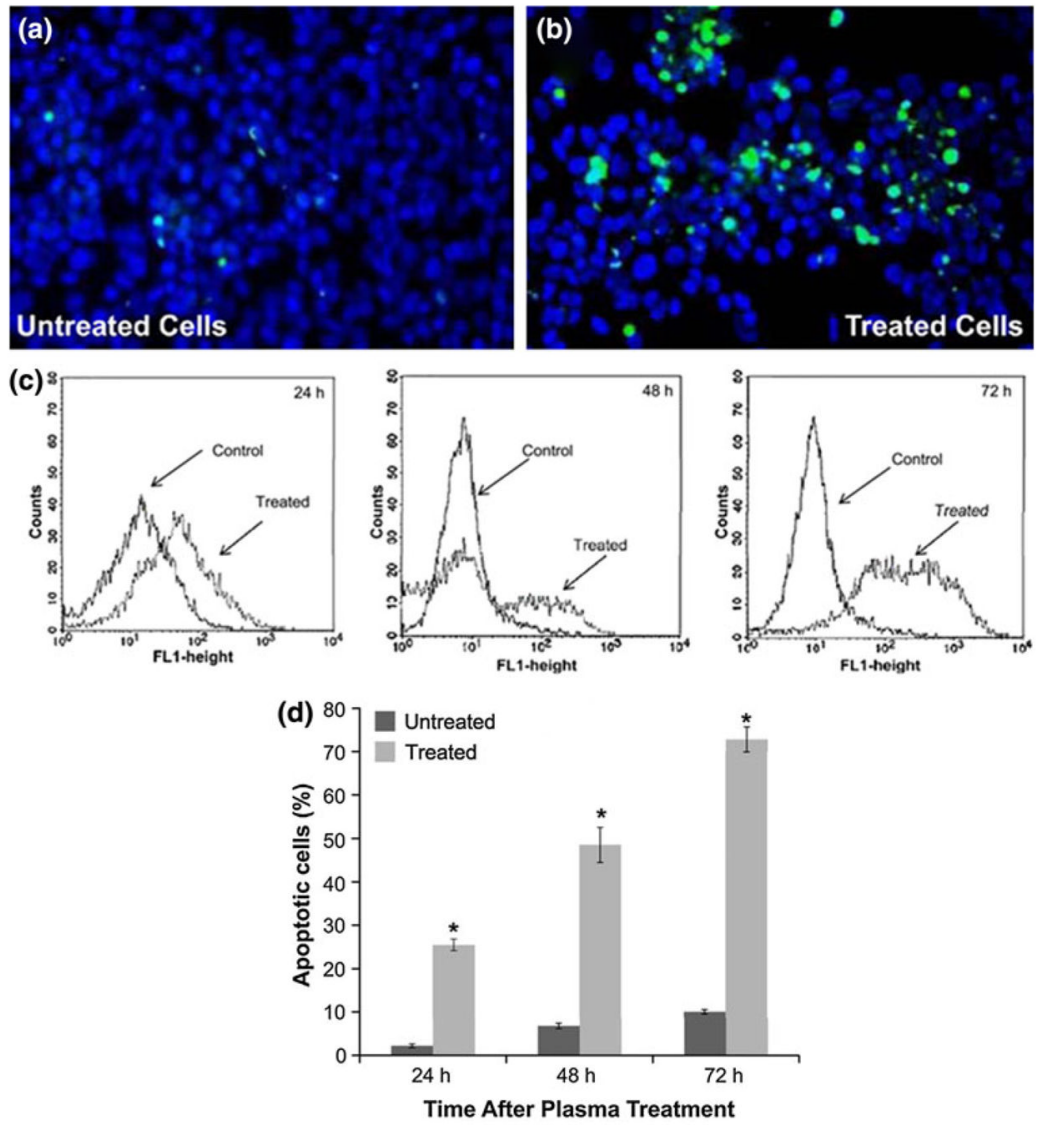

FIGURE 6.

TUNEL $^{\circledR}$ assay demonstrates that non-thermal plasma treatment induces late-stage apoptosis in melanoma cells. Images of (a) untreated and (b) treated melanoma cells following TUNEL assay. All cells are stained blue (darker circles) and apoptotic cells are also stained green (bright spots). Assay performed $24 \mathrm{~h}$ following treatment at a dose of 15 $\mathrm{J} / \mathrm{cm}^{2}$. (c) The FL1 (fluorescein) fluorescence histogram (number of events over fluorescence intensity) of a representative experiment is shown. (d) Flow cytometry was performed as described and percentage of TUNEL-positive cells from triplicate samples $( \pm \mathrm{SD})$ in untreated and treated $\left(15 \mathrm{~J} / \mathrm{cm}^{2}\right)$ samples analyzed via flow cytometry 24,48 , and $72 \mathrm{~h}$ after plasma treatment are plotted. 


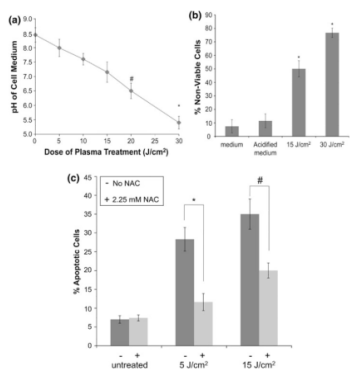

FIGURE 7.

$\mathrm{pH}$ does not play a major role in plasma-induced apoptosis, while plasma-generated intracellular ROS mediate induction of apoptosis in DBD plasma-treated melanoma cells. (a) $\mathrm{pH}$ of the medium covering the cells during treatment was measured using a micro $\mathrm{pH}$ electrode after treatment with different doses of plasma as indicated. Data from triplicate samples $( \pm \mathrm{SD})$ are plotted. (b) Melanoma cells were exposed to fresh cell growth medium or acidified cell growth medium with a $\mathrm{pH}$ of 5.4 for 1 min or plasma treated at a dose of $30 \mathrm{~J} /$ $\mathrm{cm}^{2}$ followed by incubation in fresh medium for $3 \mathrm{~h}$. Cell viability (non-viable cells stained blue) was determined $3 \mathrm{~h}$ after treatment by trypan blue exclusion test. Data from triplicate samples $( \pm \mathrm{SD})$ are plotted. (c) Melanoma cells were incubated for $1 \mathrm{~h}$ with $2.25 \mathrm{mM} \mathrm{N}$ acetyl-L-cysteine (NAC) $(+)$ or cell culture medium $(-)$, followed by treatment with the indicated dose of DBD plasma. Apoptotic activity was measured $24 \mathrm{~h}$ after plasma treatment by harvesting and staining the cells with Annexin-V/PI. Samples were run on the flow cytometer and analyzed using Gauva ${ }^{\circledR}$ software. Data from triplicate samples $( \pm \mathrm{SD})$ are plotted. * $p<0.001$ while ${ }^{\#} p<0.05$. 
(a)

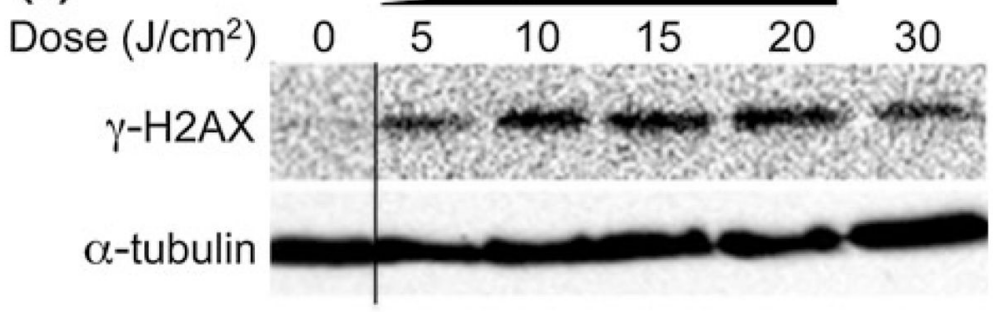

(b)

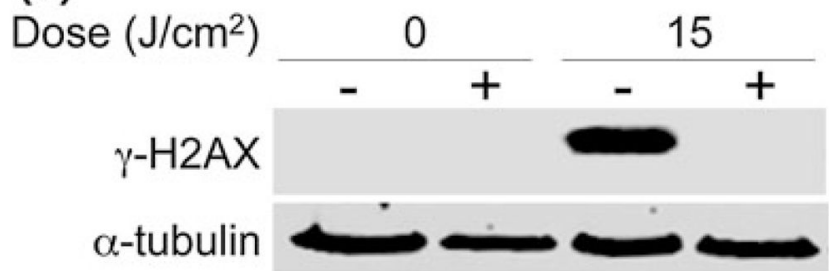

FIGURE 8.

Intracellular ROS mediates induction of DNA damage by DBD plasma. (a) Melanoma cells were treated with the indicated dose of plasma as described. After 1-h incubation, lysates were prepared and resolved by SDS-PAGE, and representative immunoblots with antibody to $\gamma$-H2AX (top) or $\alpha$-tubulin (bottom) are shown. (b) Melanoma cells were incubated for 2 h with $4 \mathrm{mM} N$-acetyl-L-cysteine (NAC) (+) or cell culture medium $(-)$, followed by treatment with the indicated dose of DBD plasma. $\gamma$-H2AX (top) or $\alpha$-tubulin (bottom) was detected by immunoblot of cell lysates prepared 1-h after plasma treatment. 


\section{TABLE 1}

Typical relative concentrations of various charged and neutral species generated by non-thermal DBD plasma in gas phase.

\begin{tabular}{ll}
\hline Plasma-generated species & Density $\left(\mathrm{cm}^{-3}\right)$ \\
\hline Superoxide $\left(\mathrm{O}_{2}^{--}\right)$ & $10^{10}$ to $10^{12}$ \\
Hydroxyl $\left(\mathrm{OH}^{-}\right)$ & $10^{15}$ to $10^{17}$ \\
Hydrogen peroxide $\left(\mathrm{H}_{2} \mathrm{O}_{2}\right)$ & $10^{14}$ to $10^{16}$ \\
Singlet oxygen $\left({ }^{1} \mathrm{O}_{2-}\right)$ & $10^{14}$ to $10^{16}$ \\
Ozone $\left(\mathrm{O}_{3}\right)$ & $10^{15}$ to $10^{17}$ \\
Nitric oxide $(\mathrm{NO})$ & $10^{13}$ to $10^{14}$ \\
Electrons $\left(\mathrm{e}^{-}\right)$ & $10^{9}$ to $10^{11}$ \\
Positive ions $\left(\mathrm{M}^{+}\right)$ & $10^{10}$ to $10^{12}$ \\
\hline
\end{tabular}

